\title{
ESTRATÉGIA DE ECLOSÃO DOS OVOS DORMENTES DE MICROCRUSTÁCEOS ENDÊMICOS DE AMBIENTES INTERMITENTES NO SUL DO BRASIL
}

\author{
Bandeira, M.G.S. ${ }^{1,}$; Martins, K.P. ${ }^{1}$; Palma-Silva, C. ${ }^{1}$; Hepp, L.U. ${ }^{2}$ \& Albertoni, E.F. ${ }^{1}$ \\ ${ }^{1}$ Universidade Federal do Rio Grande (FURG), Campus Carreiros, Laboratório de Limnologia. \\ ${ }^{2}$ Universidade Regional Integrada do Alto Uruguai e das Missões (URI), Campus Erechim, \\ Laboratório de Biomonitoramento. \\ *Autor correspondente: maiby.glorize@gmail.com
}

\begin{abstract}
Nas áreas úmidas temporárias do Sul do Brasil, o hidroperíodo tem a duração de semanas ocorrendo no inverno. Porém, ocasionalmente ocorrem curtos hidroperíodos quando há chuva nas outras estações. Os microcrustáceos são frequentemente encontrados nesses ambientes, pois produzem formas dormentes, que permite a recolonização. Para persistir ao período sem água esses organismos desenvolveram diferentes estratégias de eclosão dos ovos dormentes que variam em frequência e intensidade. Nesse estudo foi acompanhada a estratégia de eclosão de duas espécies descritas como endêmicas de ambientes temporários, Branchinecta iheringi Lilljeborg 1889 (Branchiopoda: Anostraca) e Eulimnadia pampa Marinone, Urcula \& Rabet, 2016 (Branchiopoda: Diplostraca) em diferentes hidroperíodos de áreas úmidas temporárias. Foram acompanhados quatro hidroperíodos consecutivos em três áreas úmidas, sendo três curtos (até cinco dias) e um longo, com 34 dias de alagamento. Nos hidroperíodos curtos as amostras foram coletadas depois de quatro dias após a precipitação. A primeira amostragem foi na primavera ( $\mathrm{HC} 1)$, após no verão ( $\mathrm{HC} 2)$, e no outono (HC3). Do final do outono até o inverno (hidroperíodo longo - HL), foram feitas coletas a cada dois dias. Branchinecta iheringi eclodiu em todos os hidroperíodos do ano (em HC1: $4 \pm 6,9$; HC2: $7 \pm 4,3$; HC3: $7 \pm 5,1$; HL: 35,3 \pm 43,3 organismos.m²), enquanto que $E$. pampa eclodiu somente no hidroperíodo longo (em HL: 51,6 6 61,2 organismos. $\mathrm{m}^{-2}$ ). Considerando o processo de sucessão dos ambientes temporários, ambas as espécies são resilientes nestes sistemas recolonizando os ambientes após restabelecimento do hidroperíodo. Foi observada uma diferença na resposta de eclosão entre as duas espécies, já que $B$. iheringi eclodiu em todos os hidroperíodos e E. pampa apenas no hidroperíodo de inverno. Nossos resultados sugerem que diferentes fatores além da hidratação dos ovos dormentes podem estar atuando como estímulos para eclosão em cada uma das espécies, como por exemplo, a variação de temperatura e fotoperíodo entre as estações. Porém, a hidratação é um dos principais fatores que influenciam a eclosão das formas dormentes presentes nos ambientes temporários, isso porque, estas passam por um período de dessecação entre os hidroperíodos e as espécies têm diferentes respostas a esse estímulo.
\end{abstract}

Palavras-chave: Anostraca, Diplostraca, dormência, hidroperíodo, áreas úmidas. 